\title{
The Scope of Statutory Permissiveness: Private Actions to Enforce Self-Evaluation and Transition Plans under Title II of the Americans with Disabilities Act
}

\author{
Casey R. Fronk $\dagger$
}

\section{INTRODUCTION}

Toby Tyler, a former police officer disabled in the line of duty, was convinced that his hometown's attempts to comply with the Americans with Disabilities Act (ADA) were palpably inadequate. The city claimed it was financially incapable of modifying its sidewalks and curbs in a timely manner, and it resisted Tyler's repeated requests for other facilitative adaptations. Although Tyler desired to be active in civic affairs, the city permitted its advisory committees to convene in a restaurant lacking handicap-accessible restrooms, and the City Commission refused to generate audio copies of important documents debated in its biweekly meetings. Tyler enjoyed watching tennis and baseball, and yet the city delayed constructing the handicap ramps necessary to provide egress from certain recreational viewing areas. ${ }^{2}$

After frequent but ultimately ineffective attempts to convince the city to comply voluntarily with the ADA, Tyler brought suit for injunctive relief. However, rather than premising liability solely on violations of the ADA itself, Tyler also included a more adventitious claim: that the city had failed to formulate an adequate transition plan and selfevaluation plan required by Title II's implementing regulations, which

$\dagger$ BA 2005, The Ohio State University; JD Candidate 2008, The University of Chicago.

1 Pub L No 101-336, 104 Stat 327 (1990), codified at 42 USC $\$ 12101$ et seq (2000).

2 See Tyler $v$ City of Manhattan, 857 F Supp 800, 801-12 (D Kan 1994). This case's detailed fact pattern illustrates some of the symptomatic problems facing both public entities and potential plaintiffs under the ADA. The evidence in this case, for example, suggests that the city attempted to modify facilities for the plaintiff's benefit, but was hampered by a severe lack of funds (being granted only $\$ 264,000$ in state funds for modifying architectural barriers) and sometimes comically adverse circumstances (Tyler was unable to attend a City Commission meeting scheduled to address his concerns because City Hall's sole elevator was under repair and the meeting was being held on the second floor). See id at 807-08. Potential plaintiffs, meanwhile, often face unsympathetic government officials. In this case, for example, when Tyler and his wife suggested that City Hall should be modified to allow handicap access, the City Manager retorted, "[I]f the City altered the [Hall's] threshold ... [you] would then want something else." Id at 807. 
alone articulate no right to private enforcement. ${ }^{3}$ After largely ignoring the underlying question of whether a private plaintiff had a right of action to enforce the ADA's implementing regulations, ${ }^{4}$ the district court found the city's transition plan and self-evaluation plan inadequate and enjoined the city to conduct a thorough self-evaluation and repair its inadequate transition plan. ${ }^{s}$

Although Tyler only tangentially addresses whether private plaintiffs can sue to enforce Title II's implementing regulations, subsequent decisions recognized the issue's salience ${ }^{6}$-especially in the wake of the Supreme Court's ruling in Alexander $v$ Sandoval.' The three circuits to consider this question have split. The First and Sixth Circuits hold there is no private right of action to enforce performance of selfevaluation and transition plans, while the Tenth Circuit holds that the private right of action contained in Title II extends to violations of

3 See id at 812 ("[T]he plaintiffs complaint alleges that the City of Manhattan has violated Title II of the ADA by failing to prepare and complete a self-evaluation... and ... transition plan."). This case appears to be one of the first examples of private suit for violation of Title II's implementing regulations. For other early examples, see Matthews $v$ Jefferson, $29 \mathrm{~F}$ Supp $2 \mathrm{~d} 525$, 539-40 (WD Ark 1998); McCready v Michigan State Bar, 881 F Supp 300, 306 (WD Mich 1995).

4 See Tyler, $857 \mathrm{~F}$ Supp at 812 (finding that the court had jurisdiction over the matter "under the authority of 28 U.S.C. $\S 1331$ and Title II of the Americans with Disabilities Act, 42 U.S.C. $\S 12131$ et seq." but avoiding the question of whether a plaintiff is permitted to sue to enforce violations of implementing regulations).

5 See id at 821-22:

Consequently, the City is directed to conduct a self-evaluation, consistent with 28 C.F.R. $\$ 35.105(\mathrm{a})-(\mathrm{c})$, of all of its services, practices, and policies as they exist on the date this memorandum and order is filed. The evaluation must address all services made available by the city [and] must also address the City's policies and practices ... to identify nonstructural barriers to participation by persons with disabilities.

6 See, for example, Matthews, $29 \mathrm{~F}$ Supp $2 \mathrm{~d}$ at 540 (holding that "money damages against a public entity for failure to formulate a transition plan [or self-evaluation plan] or timely comply with the plan are not available," but noting that the absence of a plan may be used to buttress a claim of discrimination); Deck $v$ City of Toledo, 76 F Supp 2d 816, 823 (ND Ohio 1999) (stating that "there is no private right of action to enforce the self-evaluation and transition plan requirements set forth in the regulations accompanying Title II").

7532 US 275 (2001). Sandoval addressed the virtually identical question of whether private plaintiffs could sue to enforce regulations promulgated under Title VI of the Civil Rights Act of 1964,42 USC $\$ 2000 \mathrm{~d}$ et seq (2000). Both courts and commentators believe that the Court's reasoning was sweeping enough to apply to all cases where a statute contained a private right of action not explicitly articulated in its implementing regulations. See, for example, Cherry v City College of San Francisco, 2005 US Dist LEXIS 41229, *7-14 (ND Cal) (assuming that Sandoval is authoritative precedent with which to analyze these types of cases); Access Living of Metropolitan Chicago v Chicago Transit Authority, 2001 US Dist LEXIS 6041, *20 (ND III) (noting that the defendant "makes much of Sandoval" before finding that Sandoval, decided after the defendant filed for summary judgment, did not "abrogate or limit plaintiffs' right to bring [the] action"); Ruth Colker, The Disability Pendulum: The First Decade of the Americans with Disabilities Act 136-38 (NYU 2005) (noting that the potential impact of Sandoval on the ADA "could be broad," and concluding that "[b]road application of Sandoval to ADA Title II could ... undermine nearly all the cases proceeding under that title"). 
these implementing regulations. ${ }^{3}$ Even though each circuit employs original reasoning, all explicitly adopt the framework delineated by Sandoval for assessing conferred private rights of action. The central question, therefore, has been whether Title II's implementing regulations "prohibit what the statute permits" and are thereby powerless to extend Title II's private right of action."

Thus, at issue in this circuit split is not a choice of test but a determination of an appropriate theory of statutory interpretation. The First and Sixth Circuits, seizing primarily on Sandoval's implicit invocation of the nondelegation doctrine, employ a textualist interpretive strategy to determine Title II's scope-and concomitantly its scope of permissibility. In contrast, the Tenth Circuit reads the Sandoval test more metaphorically, employing an intentionalist interpretive methodology to determine whether Title II's congressional drafters intended to prohibit public entities from disregarding the agency regulations at issue. Although the author of the majority opinion in Sandoval is himself an avowed textualist, ${ }^{10}$ the opinion offers ambiguous clues to the proper choice of interpretive method. Any case-based solution to the circuit split, as a result, is unlikely to emerge from a straightforward reading of Sandoval.

This Comment, cognizant of this difficulty, rejects both the intentionalist and textualist frameworks embraced by the circuit courts, arguing that Sandoval's implicit reliance on the nondelegation doctrine, compounded with a recent Supreme Court case construing retaliation claims under Title IX, provides a persuasive argument that behavior prohibited by implementing regulations can be assessed through a "contextualist" interpretive framework. More specifically, the Comment proposes that the language of Title II, evaluated under Jackson v Birmingham Board of Education's " contextualist methodology, ${ }^{12}$ encompasses general prohibitions against the failure to create a transition plan or a self-evaluation plan, and thereby confers a private

8 Compare Iverson v City of Boston, 452 F3d 94, 101 (1st Cir 2006); Ability Center of Greater Toledo v City of Sandusky, 385 F3d 901, 914 (6th Cir 2004), with Chaffin $v$ Kansas State Fair Board, 348 F3d 850, 859 n 1 (10th Cir 2003).

9 See Sandoval, 532 US at 285. The Court in Sandoval used this test to rule out the possibility that the implementing regulations prohibiting disparate impact discrimination authoritatively construed Title VI of the Civil Rights Act of 1964, which the Court interpreted to proscribe only intentional discrimination.

10 Justice Antonin Scalia writes for the majority in Sandoval. See id at 278. For Justice Scalia's adherence to textualism, see, for example, Wisconsin Public Intervenor v Mortier, 501 US 597, 621 (1991) (Scalia concurring) ("[W]e should try to give the text its fair meaning ... thereby affirming the proposition that we are a Government of laws ... . That is, at least, the way I prefer to proceed.").

11544 US 167 (2005).

12 See id at 177-78. Although Jackson is a Title IX case, its interpretive methodology explicitly relies on the Sandoval test. See id at 178 . 
right of action to enforce these implementing regulations. While no circuits have yet adopted this reasoning, the text and structure of Title II, considered with reference to its legislative milieu, satisfy the contextualist test articulated by Jackson for extending a private right of action.

This Comment proceeds in three parts. Part I discusses the origins and legislative history of Title II of the ADA and its implementing regulations, examining Sandoval's significant impact on the interpretation of Title II. Part II analyzes the circuit split, determining that both sides of the split have adopted an erroneous method of statutory interpretation. Part III engages in a thorough analysis of Title II and concludes that both the historical application of the nondelegation doctrine and the precedential force of Jackson require a contextualist reading of the Sandoval test. In conclusion, the Comment applies a contextualist framework to Title II and its implementing regulations, arguing that Title II's broadly worded text and legislative context evidence congressional intent to create a private right of action to penalize noncompliance with Title II's transition plan and self-evaluation plan regulations.

\section{TITLE II, IMPLEMENTING REGULATIONS, AND SANDOVAL}

This Part examines the interplay of Title II of the ADA and its implementing regulations, and discusses how the holding of Sandoval and its subsequent application to Title II cases defines the scope of this interplay.

\section{A. ADA Title II: Statutory Background}

Congress, concerned with statistics suggesting that over fortythree million physically and mentally disabled Americans suffered from "serious and pervasive" isolation and discrimination, enacted the ADA in $1990 .{ }^{13}$ From the beginning, the ADA evidenced congressional intent to remedy a wide swath of exclusionary practices. Thus,

13 The congressional findings stated that individuals with disabilities

continually encounter various forms of discrimination, including ... intentional exclusion, the discriminatory effects of architectural, transportation, and communication barriers, overprotective rules and policies, failure to make modifications to existing facilities and practices, exclusionary qualification standards and criteria, segregation, and relegation to lesser services, programs, activities, benefits, jobs, or other opportunities.

42 USC $\$ 12101$ (a). The implications of the forty-three million figure have been hotly debated by courts and legal scholars. Compare Colker, The Disability Pendulum at 17 (cited in note 7) (arguing that "Congress recited the $\mathbf{4 3}$ million figure as a minimum figure to suggest that a substantial portion of the American population is disabled and would benefit from the protections of the ADA"), with Sutton v United Air Lines, 527 US 471, 487 (1999) (excluding some correctable conditions from the ADA's coverage by reasoning that "[h]ad Congress intended to include all persons with corrected physical limitations among those covered by the Act, it undoubtedly would have cited a much higher number of disabled persons in the findings"). 
although the ADA was closely modeled on the existing Rehabilitation Act, ${ }^{14}$ it extended that statute's punitive reach to private actors ${ }^{15}$ in addition to state actors ${ }^{16}$ and included more precise provisions against disability discrimination. Specific language in the ADA demonstrates this intent to combat a larger number of discriminatory methods, including "outright intentional exclusion," "discriminatory effects of architectural, transportation, and communication barriers," and "exclusionary qualification standards and criteria." ${ }^{17}$

According to Congress, Title II was specifically tailored to address "passive" or "exclusionary" discrimination by local and state governments-particularly the failure to modify existing structural barriers to disability inclusion. ${ }^{18}$ Title II provides that "[s]ubject to the provisions of this subchapter, no qualified individual with a disability shall, by reason of such disability, be excluded from participation in or be denied the benefits of the services, programs, or activities of a public entity, or be subjected to discrimination by any such entity." Consequently, Title II obligates any organization classified as a "public entity" to take efforts to prevent discriminatory exclusion of any

14 Rehabilitation Act of 1973, Pub L No 93-112, 87 Stat 355, codified as amended at 29 USC $\$ 701$ et seq (2000). It appears that Congress intended to create a more sweeping prohibition against disability discrimination in the ADA, as it specifically provided for a minimum level of protection that matched the existing aegis of Rehabilitation Act $\$ 504$. See 42 USC $\$ 12201$ (a) ("Except as otherwise provided in this chapter, nothing in this chapter shall be construed to apply a lesser standard than the standards applied under Title $\mathrm{V}$ of the Rehabilitation Act of 1973 (29 USC $\$ 790$ et seq) or the regulations issued by Federal agencies pursuant to such title."). The ADA's more expansive remedial provisions were initially lauded as necessary replacements for the flawed security afforded by the Rehabilitation Act. See, for example, Timothy M. Cook, The Americans with Disabilities Act: The Move to Integration, 64 Temple L Rev 393, 394 (1991) (contending that at least in the area of combating segregation and isolation of disabled Americans, the Rehabilitation Act "ha[s] been practically a dead letter"). Actual judicial application of the ADA, however, has often resulted in narrowed avenues of relief. See Colker, The Disability Pendulum at 16 (cited in note 7) (noting that courts have construed "disability" under the ADA to exclude both persons with controllable epilepsy and those with HIV infections despite earlier rulings finding both cognizable disabilities under the Rehabilitation Act).

15 See 42 USC $\$ 12182$ (a) ("No individual shall be discriminated against on the basis of disability in the full and equal enjoyment of the goods, services, facilities, privileges, advantages, or accommodations of any place of public accommodation by any person who owns, leases (or leases to), or operates a place of public accommodation.").

16 See 42 USC \$ 12131 (defining "public entity" as “(A) any State or local government; (B) any department, agency, special purpose district, or other instrumentality of a State or States or local government; and (C) the National Railroad Passenger Corporation, and any commuter authority").

1742 USC \& 12101(a)(5).

18 See HR Rep No 101-485(II), 101st Cong, 2d Sess 95-96 (1990), reprinted in 1990 USCCAN 378 ("[W]ith respect to existing facilities used for public transportation, it shall be considered discrimination ... for the public entity to fail to operate such public transportation program or activity conducted in such facilities so that, when viewed in the entirety, it is readily accessible to and usable by individuals with disabilities.").

19 Title II $\S 202$, codified at 42 USC $\$ 12132$. 
"qualified individual with a disability." ${ }^{20}$ This broad language parallels Title II's sweeping scope of enforcement - in fact, the statute has been construed to regulate, among other things: the availability of physical access to public facilities, ${ }^{21}$ including courtrooms, ${ }^{22}$ polling places, ${ }^{23}$ prisons ${ }^{24}$ and public restrooms; ${ }^{25}$ and the availability of services such as equal educational opportunities, ${ }^{26}$ accessible transportation, ${ }^{27}$ and freedom from surcharges on specialized services. ${ }^{28}$

Perhaps due to the passively discriminatory nature of Title II harms, ${ }^{29}$ the statute explicitly authorizes a private right of action to

20 See 42 USC $\$ 12131$ (defining "a qualified individual with a disability" as an individual with a disability "who, with or without reasonable modifications to rules, policies, or practices, the removal of architectural, communication, or transportation barriers, or the provision of auxiliary aids and services, meets the essential eligibility requirements for the receipt of services or the participation in programs or activities provided by a public entity").

21 See 28 CFR \$ 35.150(a) (2006) (providing that "[a] public entity shall operate each service, program, or activity so that the service, program, or activity, when viewed in its entirety, is readily accessible to and usable by individuals with disabilities").

22 See, for example, Tennessee $v$ Lane, 541 US 509, 531 (2004) (allowing a plaintiff denied appropriate access to courts to sue his state under Title II).

23 See, for example, Spitzer $v$ County of Delaware, 82 F Supp 2d 12, 13 (NDNY 2000) (granting an injunction under Title II for disabled plaintiffs unable to access county polling sites).

24 See Pennsylvania Department of Corrections v Yeskey, 524 US 206, 210 (1998) (finding that " $[t]$ he text of the ADA provides no basis for distinguishing [a prison's recreational activities, medical services, and educational and vocational programs] from those provided by public entities that are not prisons" for purposes of applying Title II). See also United States v Georgia, 546 US 151, 157 (2006) (noting in dicta that Title II could apply to the size of prison cells).

25 See, for example, Matthews $v$ Jefferson, 29 F Supp 2d 525, 534 (WD Ark 1998) (finding a violation of Title II where a County did not provide adequately accessible restrooms in its courthouse).

26 Consider Babicz v School Board of Broward County, 135 F3d 1420, 1422 (11th Cir 1998) (dismissing Title II suit alleging failure to provide equal educational activities because plaintiffs had not exhausted potential administrative remedies); 42 USC $\S 12101$ (a)(3) (stating in the congressional findings that discrimination persists in education).

27 See, for example, DRC of Greater Washington $v$ Washington Transit Authority, 239 FRD 9, 18-19 (DDC 2006) (applying Title II to rude and inconsistent service to disabled patrons of public transportation).

28 See, for example, Klingler v Director, Department of Revenue, State of Missouri, 433 F3d 1078, 1081 (8th Cir 2006) (prohibiting surcharges on automobile placards indicative of handicapped status).

29 Since the discrimination addressed by Title II is passive in the sense that it arises from nearly imperceptible omissions, rather than deliberate and transparent actions, it appears that potential private plaintiffs have a significant informational advantage over governmental officials with regard to latent statutory violations. Compare Jeffrey Manns, Private Monitoring of Gatekeepers: The Case of Immigration Enforcement, 2006 U Ill L Rev 887, 894-95 (2006) (arguing that the ability of public enforcers to effectively reveal wrongdoing is inversely proportional to the complexity of the offense and that "informed insiders" may be best positioned to detect wrongdoing); Joseph A. Grundfest, Disimplying Private Rights of Action under the Federal Securities Laws: The Commission's Authority, 107 Harv L Rev 961, 968, 969 n 15 (1994) (describing the "symbiotic relationship between public and private enforcement of the federal securities laws" that arises partially because government actors are "strangers to transactions that give rise to allegations of fraud" and thus do not share the informational advantages of private parties involved directly in the transactions). See also J.I. Case Co v Borak, 377 US 426, 432-33 (1964), abandoned in Sandoval, 532 US at 287 (finding an implied cause of action where a statutory 
enforce its provisions. Specifically, Title II extends its "remedies, procedures, and rights" to "[a]ny person alleging discrimination on the basis of disability in violation of section 12132.", Proving this entitlement is not an empty gesture, Title II's enforcement provision unequivocally entitles private citizens to sue noncompliant public entities in federal court; thereby expressing a clear intent to abrogate state sovereign immunity. ${ }^{31}$ While the Supreme Court's recent ADA jurisprudence appears somewhat antipathetic to this circumvention of sovereign immunity, Title II's enforcement provision is nonetheless

violation of SEC requirements would have been virtually undetectable by government actors not also corporate insiders).

30 Title II $\$ 203$, codified at 42 USC $\$ 12133$ (emphasis added). See also Lane, 541 US at 517 ("Title II's enforcement provision ... authorizes private citizens to bring suits for money damages."). This statutory scheme adopts the same enforcement mechanisms found in the Rehabilitation Act of 1973. 42 USC $\$ 12133$, citing 29 USC $\$ 794 \mathrm{a}$. The Rehabilitation Act, in turn, implements the rights, procedures, and remedies available under Title VI of the Civil Rights Act of 1964 , which contains an implied private right of action. 29 USC $\$ 794 a(a)(2)$, citing 42 USC $\$ 2000 \mathrm{~d}$ et seq. But see Alexander $v$ Choate, 469 US 287, 293 n 7 (1985) (warning that "too facile an assimilation of Title VI law to $\S 504$ must be resisted").

31 See 42 USC $\$ 12202$ :

A State shall not be immune under the eleventh amendment to the Constitution of the United States from an action in Federal or State court of competent jurisdiction for a violation of this chapter. In any action against a State for a violation of the requirements of this chapter, remedies (including remedies both at law and in equity) are available for such a violation to the same extent as such remedies are available for such a violation in an action against any public or private entity other than a State.

The Eleventh Amendment proscribes suits "against one of the United States by citizens of another State" and by the state's own citizens, see Hans v Louisiana, 134 US 1, 15 (1890) (holding that allowing an individual to bring suit against a state would "strain the constitution and the law to a construction never imagined or dreamed of"). Yet Congress is empowered to, "in determining what is 'appropriate legislation' for the purpose of enforcing the provisions of the Fourteenth Amendment, provide for private suits against States or state officials which are constitutionally impermissible in other contexts." Fitzpatrick v Bitzer, 427 US 445, 456 (1976).

32 Two recent cases address the ADA's abrogation of state sovereign immunity. In Board of Treasurers of the University of Alabama v Garrett, 531 US 356, 374 (2001), the Court found ADA's Title I abrogation of state sovereign immunity invalid as applied to state employment practices. While some commentators believe Garrett poses severe problems to Title II's abrogation of state sovereign immunity, see, for example, Alison Tanchyk, Comment, An Eleventh Amendment Victory: The Eleventh Amendment vs. Title II of the ADA, 75 Temple L Rev 675, 675 (2002) ("The days when a disabled individual could sue a state for monetary damages under Title II ... are numbered."), the Court's subsequent decision in Lane, 541 US at 509, ameliorated some of this concern by determining that Title II's abrogation of state sovereign immunity would be resolved on an as-applied basis. See id at 530 ("[N]othing in our case law requires us to consider Title II, with its wide variety of applications, as an undifferentiated whole."). Lane confined its factual holding to the accessibility of judicial services, leaving Title II's remaining applications in flux, but there are indications that the Court will not extend Title II's abrogation of state sovereign immunity beyond court access. See id at 549-54 (Rehnquist dissenting). While the sovereign immunity question is relevant to the ability of private parties to bring lawsuits under Title II's implementing regulations, it is beyond the scope of this Comment and will not be addressed herein, since the cases involved include local entities not implicated by Lane. See Alden v Maine, 
capable of accommodating several alternative avenues of relief. Namely, Title II licenses suits against "any state or local government" and "any department, agency, special purpose district, or other instrumentality of a State or States or local government," oblige plaintiffs to exhaust available administrative remedies before pursuing a private action against any nonfederal public entity.

A plaintiff successfully proving a violation of Title II may be entitled to several types of relief. Since Title II adopts the remedial portion of Title VI of the Civil Rights Act of $1964,{ }^{35}$ the Supreme Court has equated Title II remedies with those generally available pursuant to the Spending Clause. ${ }^{36}$ Although an individual may not be awarded punitive damages in a Title II action, ${ }^{37}$ compensatory damages or injunctive relief are available. ${ }^{38}$ Nevertheless, compensatory damages in these cases are likely to be small and highly speculative, and require a showing of intentional discrimination.

527 US 706, 756 (1999) ("The second important limit to the principle of sovereign immunity is that it bars suits against States but not lesser entities.") (emphasis added).

3342 USC $\$ 12131$ (1)(A)-(B) (emphasis added).

34 Administrative remedies are also available under Title II. An individual may file a complaint with "any agency that he or she believes to be the appropriate agency ... or with any agency that provides funding to the public entity that is the subject of the complaint, or with the Department of Justice for referral" within 180 days of the violation. 28 CFR $\$ 35.170$ (c) (2006). The selected agency must investigate the complaint and attempt informal resolution, 28 CFR $\S 35.172$, but if this informal process fails, the agency may refer the matter to the Assistant Attorney General for litigation. See 28 CFR $\$ \S 35.172-.173$. In addition, the Department of Justice may seek to revoke federal funding in order to induce compliance. 28 CFR $\S 42.108$. A plaintiff is not required to exhaust these available remedies, however, before initiating a private suit. See Cannon v University of Chicago, 441 US 677,706 n 41 (1979) (finding that there is no exhaustion requirement under Title IX of the Civil Rights Act, which is based, like the ADA, on the same enforcement procedures drawn from Title VI of the Civil Rights Act). See also Camenisch $v$ University of Texas, 616 F2d 127, 135-36 (5th Cir 1980), vacated on other grounds, 451 US 390, 398 (1981) (holding that there is no requirement of exhaustion under $\$ 504$ of the Rehabilitation Act); HR Rep No 101-485(II), 101st Cong, 2d Sess 98 (1990), reprinted in 1990 USCCAN 381 ("II]t is not the Committee's intent that persons with disabilities need to exhaust Federal administrative remedies before exercising their private right of action.").

35 Pub L No 88-352, 78 Stat 253, codified as amended at 42 USC $\$ 2000$ e et seq (2000).

36 See Barnes $v$ Gorman, 536 US 181, 184-89 (2002) (noting that the remedies under the Spending Clause are similar to those that are created by breach of contract at common lawthus, "a recipient may be held liable ... for intentional conduct that violates the clear terms of the relevant statute, but not for its failure to comply with vague language describing the objectives of the statute") (citations omitted).

37 See id at 189.

38 See Peter Blanck, et al, Disability Civil Rights Law and Policy 16-8 to -11 (West 2004) (surveying relevant case law to conclude that compensatory damages are available under ADA Title II); Barnes, 536 US at 187 (concluding that because injunctive relief "is traditionally available in suits for breach of contract," it is similarly available under Title II).

39 See Barnes, 536 US at 187 (providing for recovery only in cases of "intentional conduct"). In these cases, "intentional discrimination" requires that the authorized official has "actual knowledge of discrimination" and "fails adequately to respond." Gebser v Lago Vista Independent School District, 524 US 274, 290 (1998) (defining intentional discrimination for Title IX 
Despite the uncertainty of damages relief, Title II's private right of action provides an integral enforcement mechanism for structural disability discrimination. An estimated fifty-four million people in the United States are classified as "disabled" under the ADA. "These individuals, faced with discrimination, cannot always turn to state law in the absence of ADA protection. ${ }^{41}$ In fact, a recent study finds that state law provides relief equivalent to Title II in only thirty-five states, ${ }^{42}$ and only twenty-four states possess disability discrimination statutes with coverage analogous to Title II. $^{43}$ While administrative remedies are available, studies have indicated that administrative enforcement of the ADA is rather desultory."

\section{B. Self-Evaluation Plan and Transition Plan Regulations}

Self-evaluation plan and transition plan requirements are among a number of implementing regulations promulgated by the Attorney General under the authority of the ADA. Section 204 of Title II authorizes the Attorney General to "promulgate regulations ... that implement [Title II of the ADA]." " In response to this mandate, the Attorney General fashioned a diverse series of regulations, ${ }^{46}$ two of which require public entities to create, within one year of passage of the ADA, a selfevaluation plan and a transition plan to facilitate programmatic and structural modification." The self-evaluation regulation requires a public entity to "evaluate its current services, policies, and practices, and the effects thereof" and modify "any such services, policies, and practices" that

of the Civil Rights Act). See also Ferguson v City of Phoenix, 157 F3d 668, 674 (9th Cir 1998) (adopting Gebser's definition for Title II).

40 See Matthew D. Taggart, Comment, Title II of the Americans with Disabilities Act after Garrett: Defective Abrogation of Sovereign Immunity and Its Remedial Impact, $91 \mathrm{Cal} \mathrm{L} \mathrm{Rev} \mathrm{827,}$ 829 (2003) (quoting a Census Bureau finding).

41 See Colker, The Disability Pendulum, at 154-64 (cited in note 7) (surveying the remedies for disability discrimination under fifty states' regulatory regimes and concluding that state law alone is often an inadequate guard against disability discrimination).

42 See id at 154 (noting that nine states have no enforcement mechanism against state violations and seven others limit potential remedies under Title II).

43 See id at 160.

44 See National Council on Disability, Promises to Keep: A Decade of Federal Enforcement of the Americans with Disabilities Act 33-150 (2000), online at http://www.ncd.gov/newsroom/ publications/2000/pdf/promises.pdf (visited Sept 29, 2007) (describing the administrative enforcement procedures of Title II and finding that filing and resolving a complaint was often a lengthy and laborious process). Particularly problematic is the protracted complaint process: in many cases, the time elapsed after a complaint is filed precludes a private suit under a statute of limitations. See id at 74.

45 Title II § 204(a), codified at 42 USC \$ 12134(a).

46 See 28 CFR \& 35.101 et seq (2006).

47 The effective date of the ADA was January 26,1992 . Thus, by January 26,1993 , every public entity was required to have created a transition plan and a self-evaluation plan. See Chaffin v Kansas State Fair Board, 348 F3d 850, 862 (10th Cir 2003). 
violate Title III. ${ }^{48}$ The transition plan regulation mandates that any public entity obliged to undertake "structural changes to facilities" to meet ADA standards "shall develop ... a transition plan setting forth the steps necessary to complete such changes." "9

Neither the self-evaluation plan nor the transition plan regulation contains an explicit private right of action to remedy noncompliance. ${ }^{50}$ If a private right of action to enforce the regulations exists, therefore, it must be implied either from Title II's explicit provision or through the text and grammatical structure of the implementing regulations." Sandoval, however, severely circumscribes the type of private actions that can be connoted to extend to implementing regulations. Given the difficulties of obtaining a regulatory remedy for noncompliance, ${ }^{52}$ these private actions are often a more palatable option for enforcement-and an inability to bring such suits could severely restrict plaintiffs' actual relief under Title II.

\section{Sandoval}

Although Sandoval concerned implementing regulations promulgated under Title VI of the Civil Rights Act, its impact on ADA Title II has been rightly recognized as potentially momentous. Since Title II

4828 CFR $\$ 35.105$ (a). The self-evaluation requirement involves two steps. The public entity must initially catalogue all of its "programs, activities, and services." U.S. Department of Justice, The Americans with Disabilities Act Title II Technical Assistance Manual \$ II-8.2000, online at http://www.usdoj.gov/crt/ada/taman2.html (visited Sept 29, 2007). Subsequently, the public entity must "[r]eview all the policies and practices that govern the administration of [its] programs, activities, and services." Id. When undertaking this review, the public entity should determine whether any of its policies or practices "adversely affect the full participation of individuals with disabilities." Id. The DOJ's Title II Technical Assistance Manual suggests that the following areas in particular require "careful examination": the existence of "physical barriers to access"; communication discrepancies between disabled and nondisabled individuals; "procedures to evacuate individuals with disabilities during an emergency"; accessibility of new construction projects; the familiarity of employees with "policies and practices for the full participation of individuals with disabilities"; and the potential discriminatory effects of hiring. Id. The regulation also requires a public entity to initiate a public forum for comment on the plan, 28 CFR $\S 35.105$ (b), and, if it employs more than fifty people, to maintain on file for three years after the self-evaluation "[a] list of the interested persons consulted; [a] description of areas examined and any problems identified; and [a] description of any modifications made." 28 CFR $\$ 35.105$ (c).

4928 CFR $\S 35.150$ (d). A transition plan must, at a minimum: "Identify physical obstacles ... that limit accessibility"; "[d]escribe in detail the methods that will be used to make the facilities accessible"; create a schedule for implementation; and "[i]ndicate the official responsible for implementation of the plan." 28 CFR $\$ 35.150$ (d)(3). See also Title II Technical Assistance Manual § II-8.3000 (cited in note 48).

50 See 28 CFR $\S \S 35.105,35.150$ (d).

51 See Sandoval, 532 US at 291 ("Language in a regulation may invoke a private right of action that Congress through statutory text created, but may not create a right that Congress has not.").

52 See notes 29 and 44 . 
is patterned on $\S 504$ of the Rehabilitation Act, which itself is derived structurally from Title VI, both commentators ${ }^{53}$ and defendants in lower courts ${ }^{\text {s4 }}$ have identified Sandoval's potentially deleterious effect on private enforcement of Title II's implementing regulations. Indeed, as detailed in Part II, Sandoval has been applied ubiquitously to the transition plan and self-evaluation plan regulations under Title II. Nevertheless it is far from clear that Sandoval, which was decided on principles of statutory interpretation rather than constitutional grounds, creates a generally applicable rule for the derivation of private rights of action.

The dispute at issue in Sandoval began in 1990, when the state of Alabama amended its Constitution, designating English as the official state language. ${ }^{s s}$ The Alabama Department of Public Safety, directed by James Alexander, required all driver's license exams to be taken in English. ${ }^{56}$ Martha Sandoval, a non-English speaking resident of Alabama, sued, claiming the driver's exam regulation violated Title VI of the Civil Rights Act of 1964's implementing regulation forbidding recipients of federal financial assistance to "utilize criteria or methods of administration which have the effect of subjecting individuals to discrimination because of their race, color, or national origin." ${ }^{, 8}$ Like the transition plan and self-evaluation plan regulations promulgated under Title II, the regulation at issue in this case did not itself contain language creating a private cause of action to remedy its violation.

The Supreme Court, granting certiorari, held that the implied private right of action in Title VI of the Civil Rights Act of 1964 did not extend to disparate-impact regulations promulgated under Title VI's authority. ${ }^{39}$ Declaring that "private rights of action to enforce federal law must be created by Congress," ${ }^{60}$ the Court recognized that a statutory cause of action can be construed to cover a statute's implementing regulation where that regulation "authoritatively construe[s] the

53 See, for example, Colker, The Disability Pendulum at 138 (cited in note 7) ("The impact of the Sandoval decision could be broad under the ADA, because few cases under ADA Title II involve examples of intentional discrimination.").

54 See, for example, Access Living of Metropolitan Chicago v Chicago Transit Authority, 2001 US Dist LEXIS 6041, *20 (ND III) ("Defendant makes much of Sandoval, which was decided after [defendant] filed its motion for summary judgment.").

5s See 532 US at 278-79.

56 See id.

57 Title VI of the Civil Rights Act of 1964 provides that no person shall "on the ground of race, color, or national origin, be excluded from participation in, be denied the benefits of, or be subjected to discrimination under any program or activity" covered by Title VI. See 42 USC $\$ 2000 d$.

5828 CFR $\& 42.104(\mathrm{~b})(2)$ (2006).

59 See Sandoval, 532 US at 293. The Court first determined that an implied private right of action was available under $\S 601$ of the statute. See id at 279-80, citing Cannon,441 US at 694-99.

60 Sandoval, 532 US at 286. 
statute itself." ${ }^{\text {,61 }}$ Nevertheless, the Court found that Congress only intended to prohibit intentional discrimination under $\$ 601$, not disparate-impact discrimination as proscribed by the implementing regulation. ${ }^{62}$ Because $\S 601$ of Title VI only prohibits intentional discrimination, the Court stated that regulations prohibiting activities that disparately impact racial groups "do not simply apply $\S 601$ - since they indeed forbid conduct that $\$ 601$ permits." ${ }^{63}$ Thus, the private action to enforce $\S 601$ was not available to enforce its implementing regulations. ${ }^{64}$

\section{THE CIRCUIT SPLIT}

Each of the three circuits to consider whether there is a private cause of action to enforce Title II's implementing regulations has employed the Sandoval "prohibits what the statute permits" test. The Tenth Circuit has held that plaintiffs have a private cause of action to enforce the self-evaluation plan and transition plan regulations because the regulations echo Title II's broad conception of discrimination. ${ }^{65}$ The First and Sixth Circuits, in contrast, have concluded that there is no private right of action to enforce these implementing regulations since the harm wrought through lack of a transition plan or self-evaluation plan is, if not ephemeral, thoroughly distinct from the type of harm Title II's language seeks to remedy. This Part examines the reasoning of the circuit courts and argues that the disagreement is one of interpretive methodology: two courts utilize a textualist interpretive strategy, while the other employs an intentionalist analysis.

\section{A. Sandoval's Interpretive Vacuum}

Although Sandoval imparts a linguistically simple test for determining whether an implementing regulation is enforceable through a

61 Id at 284, citing Chevron U.S.A. Inc v NRDC, 467 US 837, 843-44 (1984) ("[I]t is therefore meaningless to talk about a separate cause of action to enforce the regulations apart from the statute [since a] Congress that intends the statute to be enforced through a private cause of action intends the authoritative interpretation of the statute to be enforced as well.").

62 Sandoval, 532 US at 280-86. Justice Scalia, author of the majority opinion, cites Guardians Association v Civil Service Commission of the City of New York, 463 US 582 (1983), as establishing $\$ 601$ 's boundaries to proscribe only intentional discrimination. Sandoval, 532 US at 281.

63 Sandoval, 532 US at 285 (emphasis added), citing Central Bank of Denver v First Interstate Bank of Denver, 511 US 164, 173 (1994) ("[A] private plaintiff may not bring [a suit based on a regulation] against a defendant for acts not prohibited by the text of [the statute].").

64 See Sandoval, 532 US at 285.

65 See Chaffin v Kansas State Fair Board, 348 F3d 850, 859 n 1 (10th Cir 2003).

66 See Ability Center of Greater Toledo v City of Sandusky, 385 F3d 901, 914 (6th Cir 2004). The First Circuit, relying more explicitly on Title II's statutory language, has concluded that since the self-evaluation and transition plan regulations do not in themselves render facilities and programs inaccessible to the disabled, there is no private right of action to enforce the regulations. See Iverson v City of Boston, 452 F3d 94, 101 (1st Cir 2006). 
private right of action, it offers lower courts little guidance on the test's application, thereby creating an interpretive vacuum in which two competing approaches have developed. Sandoval finds the disparate-impact regulations at issue not privately enforceable simply because "they ... forbid conduct that $\S 601$ permits." "Wh While this statement is the conclusion of an extensive investigation of prior precedent determining the scope of $\S 601$, it appears that the circuit courts applying the test employ it aphoristically-perhaps to validate their own opportunistic reasoning. Notably, there is no specific indication in Sandoval that the "prohibits what the statute permits" test should preclude a rigorous investigation of legislative intent. ${ }^{68}$ Perhaps in response to this interpretive ambiguity, circuits utilizing the test have applied two competing modes of statutory interpretation. The first, as elucidated in the Sixth and First Circuits in Ability Center of Greater Toledo $v$ City of Sandusky ${ }^{69}$ and Iverson $v$ City of Boston, ${ }^{70}$ respectively, is predominantly "textualist": it focuses on the text of the organic statute to determine statutory scope and downplays the efficacy of legislative history in determining congressional intent. The second, as expounded by the Tenth Circuit in Chaffin $v$ Kansas State Fair Board ${ }^{71}$ is better classified as "intentionalist": it focuses on legislative history and the "broad purposes" motivating the statutory language to place the organic statute in its proper interpretive context.

67532 US at 285.

68 Consider id at 281, citing Guardians Association v Civil Service Commission of the City of New York, 463 US 582, 610-12, 642 (1983). The opinions in Guardians delve deeply into the legislative history of $\S 601$. See, for example, Guardians, 463 US at 610-11 (Powell concurring) ("[I]n view of the clear legislative intent, Title VI must be held to proscribe only [intentional] racial classifications. ... Justices Brennan, White, Marshall, and Blackmun undertook a thorough analysis of the legislative history in reaching the same conclusion."), quoting Regents of the University of California v Bakke, 438 US 265, 287 (1978). But consider Sandoval, 532 US at 285-86, citing Central Bank, 511 US at 173 (finding that "a private plaintiff may not bring a [suit based on a regulation] against a defendant for acts not prohibited by the text of [the statute]") (emphasis added). The Court in Central Bank, however, based its textualist interpretation of 17 CFR $\S 240.10 \mathrm{~b}-5$ (1993), an implementing regulation of the Securities Exchange Act of 1934, on context-specific precedent interpreting $\S 10$ (b) narrowly. See Central Bank, 511 US at 173-78 ("It is inconsistent with settled methodology in $\$ 10$ (b) cases to extend liability beyond the scope of conduct prohibited by the statutory text."). But also consider Sandoval, 532 US at 314-15 (Stevens dissenting) (disagreeing with the majority's test because "[t]here is simply no reason to assume that Congress contemplated, desired, or adopted a distinction between regulations that merely parrot statutory text and broader regulations.") (emphasis added).

69385 F3d 901 (6th Cir 2004).

$70 \quad 452$ F3d 94 (1st Cir 2006).

71348 F3d 850 (10th Cir 2003). This case involved three plaintiffs, all disabled patrons of the Kansas State Fair, who sued for injunctive relief after each suffered discomforting experiences at the fairgrounds. See id at 850, 853-54. 


\section{B. Two Interpretive Methodologies}

1. The First and Sixth Circuits: a literal interpretation of the text.

In response to the interpretive freedom ostensibly provided by Sandoval, two circuits have precluded private suits to enforce certain Title II implementing regulations, concluding that the transition plan and self-evaluation plan requirements "forbid conduct that the statute permits." In Ability Center, the Sixth Circuit applied the Sandoval framework to a suit brought by individuals against the City of Sandusky for failing to implement a transition plan, determining that $\$ 35.150$ (d) "creates obligations not necessarily required by [Title II]" and thereby cannot be enforced through a private right of action derived from Title II. ${ }^{22}$ Likewise, in a case brought by an individual against the City of Boston for failing to evaluate and modify facilities that violate the ADA, the First Circuit, in Iverson, held that no private right of action exists to enforce either the transition plan or selfevaluation plan regulation because both implementing regulations "impose[] an obligation beyond the [ADA] mandate."

Although each of the circuits couches its interpretation of Sandoval's test in slightly different terminology, both ultimately scrutinize Title II's text to determine whether the implementing regulations circumscribe behavior beyond Title II's regulatory scope. The Sixth Circuit interprets the test as one of considering whether the transition plan regulation creates obligations on public entities "explicitly contemplated" by Title II. ${ }^{74}$ Its application is unabashedly textualist: to decide whether a regulation is "explicitly contemplated," there must be some unambiguous indication in the statute's text that the implementing regulation is "integral to the achievement of the statute's aims or that Congress considered a public entity's failure to adopt such a [regulation] as a form of discrimination against disabled individuals." The First Circuit adopts an even stricter test: if "it

$72385 \mathrm{~F} 3 \mathrm{~d}$ at 914 ("[I]t is conceivable that a public entity could fully satisfy its obligations to accommodate the disabled while at the same time fail to put forth a suitable transition plan.").

73452 F3d at 101-02. Notably, the plaintiffs also brought a coterminous claim under $\S 504$ of the Rehabilitation Act, perhaps anticipating a more favorable judgment under the older statute. See id at 97 . Nevertheless, the First Circuit construed the claims concurrently, ruling that there was no private right of action under either the Rehabilitation Act or Title II for enforcement of the self-evaluation plan regulation. See id.

74 See Ability Center, 385 F3d at 913 ("If $§ 35.150$ (d) imposes obligations not explicitly contemplated by Title II, then it is not enforceable through the Act's private cause of action.").

75 Id at 914 (finding that "there is no indication that Congress conceptualized of transition plans or the failure to adopt them in this manner"). The court finds that although the transition plan regulation

may create a procedural requirement that encourages public entities to consider and plan ways in which they will accommodate the disabled, and it may ultimately facilitate compli- 
is ... conceivable that a public entity may be in full compliance with [the organic statute] without observing the commands of the [implementing] regulation[s]," no private right of action is available to enforce the regulations. ${ }^{36}$ This test requires only an analysis of the organic statute's text-since "[n]othing in the text of Title II requires public entities to conduct self-evaluations, let alone do so by the date prescribed in the regulations," the self-evaluation plan is not privately enforceable, since it "impose[s] obligations on public entities different than, and beyond, those imposed by the ADA itself." $"$

\section{The Tenth Circuit: searching for Congress's "broad intent."}

The Tenth is the solitary circuit to allow private plaintiffs to sue to enforce the transition plan and self-evaluation plan regulations. In Chaffin, the Tenth Circuit found that the transition plan and selfevaluation plan regulations simply "provide the details necessary to implement the statutory right created by $\S 12132$ of the ADA" and therefore "do not prohibit otherwise permissible conduct" under the Sandoval test. ${ }^{78}$ In conclusion, it held that Title II's private right of action extended to its implementing regulations, which are "an authoritative and reasonable interpretation of Title II."

Unlike the First and Sixth Circuits, the Tenth construes Sandoval to allow, or even require, a thorough investigation into the legislative history of the organic statute through an interpretive strategy best classified as "intentionalist." The court in Chaffin bases its holding on Congress's purpose in passing the ADA, finding that Congress in-

ance with Title II, ... there is no indication that a public entity's failure to adopt a transition plan harms disabled individuals, let alone in a way that Title II claims to prevent or redress.

Id. Ultimately, the test looks to the literal meaning of the statute. See id (noting that the language of Title II cannot be construed to include transition plan requirements).

76 Iverson, 452 F3d at 101.

77 Id at 101-02 (emphasis added). Unlike the Tenth Circuit, which construes the statutory text expansively, the First gives Title II's text the narrowest credible interpretation.

78 Id at 858. According to the Tenth Circuit, "Sandoval holds only that regulations may not create a private cause of action where no such right was intended by Congress in the statute authorizing promulgation of such regulations." Id at 857 (emphasis added). Accordingly, the court's focus is on the broader objectives of Congress when enacting the statute. See id at 858-59 (evaluating Congress's intent when passing Title II).

79 Id at $859 \mathrm{n} 1$ (noting that once the implementing regulations are determined to be the authoritative and reasonable interpretation of the organic statute, it is unnecessary to evaluate Congress's intent to create a private remedy to enforce the regulations).

80 But see Ability Center, 385 F3d at 912 (using legislative history to determine the scope of Title II in relation to another implementing regulation, 28 CFR $\$ 35.151$, which requires curb alterations). The Sixth Circuit's use of legislative history to validate a private right of action to enforce 28 CFR $\$ 35.151$, compared with its failure to discuss legislative history with respect to the transition plan regulation, is somewhat surprising, suggesting perhaps that the Sixth Circuit construes the transition plan regulation to so obviously overextend the plain meaning of Title II that interpretive recourse to legislative history is pointless. 
tended to "prohibit[] a broad, comprehensive concept of discrimination, beyond discrimination motivated by a hostile discriminatory purpose." ${ }^{81}$ Distinguishing Sandoval, the Tenth Circuit reasons that in contrast to Title VI, the ADA regulates disparate impact discrimination. ${ }^{82}$ Critical to this analysis is an examination of Title II's legislative history. Specifically, the court focuses on the congressional goal when enacting the ADA of providing disabled individuals with "equality of opportunity, full participation, independent living, and economic selfsufficiency." Additionally, the court inquires into the historical context of the ADA, referencing Congress's intent to equate Title II with $\S 504$ of the Rehabilitation Act, which had been previously interpreted to prohibit disparate-impact discrimination."

\section{Textualism, Intentionalism, and the ADA}

This circuit split mirrors what many commentators have recognized as a theoretical debate over statutory interpretation waged within the Supreme Court in the last few decades. ${ }^{85}$ Although traditionally courts have looked first to the statutory text, their reliance on text has been limited at best. ${ }^{86}$ In fact, courts often have resorted to a variety of nontextual sources to determine congressional intent in the

81 Chaffin, 348 F3d at 858 . The Chaffin court contrasts this intent with that of Congress when promulgating Title VI of the Civil Rights Act, claiming that with Title II Congress intended to prohibit architectural and structural discrimination against individuals with disabilities. See id.

82 See id at 859-60 (relying on the legislative history of the ADA, and particularly the remedial parallels between the ADA and the Rehabilitation Act, to conclude that Title II reaches disparate impact discrimination).

83 Id at 858, quoting 42 USC $\$ 12101$ (a)(8).

84 See Chaffin, 348 F3d at 858-60. The court first remarks that Congress intentionally decided "not to list all the types of actions that are included within the term 'discrimination' [under Title II] ... because [Title II] essentially simply extends the anti-discrimination prohibition embodied in section 504 [of the Rehabilitation Act].” Id at 858-59, quoting HR Rep No 101-485(II), 101st Cong, 2d Sess 84 (1990), reprinted in 1990 USCCAN 367. The court then turns to Rehabilitation Act precedent to argue that $\S 504$ was designed to prohibit disparate impact discrimination. See Chaffin, 348 F3d at 859, quoting Alexander v Choate, 469 US 287, 295 (1985) (construing $\S 504$ to include discrimination caused by "thoughtlessness and . . benign neglect").

85 See generally Thomas W. Merrill, Textualism and the Future of the Chevron Doctrine, 72 Wash U L Q 351 (1994) (remarking on textualism's influence on the Supreme Court over the past decade); Frederick Schauer, Statutory Construction and the Coordinating Function of Plain Meaning, 1990 Sup Ct Rev 231 (detailing the Supreme Court's use of "plain meaning" as an alternative to a full-blown inquiry into congressional intent). See also Richard J. Pierce, Jr., Justice Breyer: Intentionalist, Pragmatist, and Empiricist, 8 Admin L J Am U 747, 747 (1995) (recognizing the Court's interpretive debate).

86 See William N. Eskridge, Jr., The New Textualism, 37 UCLA L Rev 621, 625-26 (1990) (commenting that courts traditionally used a "soft plain meaning rule," by which "the plainest meaning can be trumped by contradictory legislative history"). 
face of ambiguous textual imperatives. ${ }^{87}$ This interpretive strategy is now generally termed "intentionalism" because it focuses on congressional intent. In contrast, textualism requires statutory interpretation that depends primarily on the "plain meaning" of a statute. In the face of textual ambiguities, textualists employ dictionaries, grammar books, and the traditional common law canons of construction to decipher meaning. ${ }^{90}$ Although textualist attitudes towards legislative history are not monolithic, several prominent textualists have eschewed legislative history entirely. ${ }^{91}$ The recent rise to prominence of textualist inquiry has been called influential and even "agenda-setting" in judicial statutory interpretation, as textualism challenged intentionalism's ascendancy in the interpretive arena.

Certainly with respect to interpretation of the ADA, textualism has proven a dominant force in restricting the statute's scope. The

87 See id (stating that "almost anything that casts light upon what Congress attempted to do when it enacted a statute is potentially relevant," including appendices in committee reports, stateménts by law professors, and legislative silence).

88 See Martin H. Redish and Theodore T. Chung, Democratic Theory and the Legislative Process: Mourning the Death of Originalism in Statutory Construction, 68 Tulane L Rev 803, 813-15 (1994) ("Intentionalism asks how the enacting legislature would have decided the interpretive question facing the court."). For examples of an intentionalist strategy employed by the Supreme Court in disability cases, see Wendy E. Parmet, Plain Meaning and Mitigating Measures: Judicial Construction of the Meaning of Disability, in Linda H. Krieger, ed, Backlash against the ADA: Reinterpreting Disability Rights 122, 133 (Michigan 2003) (finding intentionalism "well exemplified" by Justice Brennan's inquiry into the meaning of "handicap" in the Rehabilitation Act in School Board of Nassau County v Arline, 480 US 273 (1987)).

89 See Antonin Scalia, A Matter of Interpretation: Federal Courts and the Law 23 (Princeton 1997) ("A text ... should be construed reasonably, to contain all it fairly means."). See also Dunn $v$ Commodity Futures Trading Commission, 519 US 465, 480 (1997) (Scalia concurring) ("[T]he purposes underlying the Treasury Amendment are most properly fulfilled by giving effect to the plain meaning of the language as Congress enacted it.").

90 See William N. Eskridge, Jr., Textualism, The Unknown Ideal?, 96 Mich L Rev 1509, 1532 (1998) ("A new textualist considers plenty of context for figuring out the plain meaning of a statutory provision: the whole statute in which the provision is situated, dictionaries and grammar books, at least some canons of statutory construction, and the common sense that God gave us."). See also Note, Looking It Up: Dictionaries and Statutory Interpretation, 107 Harv L Rev $1437,1438-40$ (1994) (identifying an increasing use of dictionary citations in published Supreme Court opinions). For a textualist theory of canons of construction, see Scalia, $A$ Matter of Interpretation at 25-29 (cited in note 89 ).

91 See, for example, Thompson $v$ Thompson, 484 US 174, 191-92 (1998) (Scalia concurring) (stating that "[c]ommittee reports, floor speeches, and even colloquies between congressmen ... are frail substitutes for bicameral vote upon the text of a law and its presentment."). Although this total renunciation of legislative history is not unavoidably textualist, two major advocates of textualism, Justices Thomas and Scalia, have a dim view of legislative history's interpretive efficacy. See Connecticut National Bank $v$ Germain, 503 US 249, 253-54 (1992) (Thomas) ("We have stated time and again that courts must presume that a legislature says in a statute what it means and means in a statute what it says there."); Scalia, $A$ Matter of Interpretation at 29-37 (cited in note 89) (concluding that "legislative history should not be used as an authoritative indication of a statute's meaning").

92 See Eskridge, 96 Mich L Rev at 1514 (cited in note 90). 
most prominent example of textualist methodology in the disability setting involves the question of whether mitigating measures should be considered in determining disability-debated in Sutton $v$ United Airlines, Inc. ${ }^{93}$ In Sutton, Justice O'Connor found grammatical structure determinative, concluding that the ADA's definition of disability in "the present indicative verb form" indicated the Act was concerned only with protecting individuals with a disability not presently correctable." Despite suggestions in the congressional record directly contrary to O'Connor's conclusion, ${ }^{95}$ her textualist argument was able to capture a majority. Sutton's ostensibly counterintuitive result, coupled with other recent decisions, has prompted one commentator to observe that " $[t]$ he commitment to textualism among at least a majority of the [Rehnquist] Court tends to preclude both a resort to the ADA's rich legislative history and deference to the administrative agency, and to foster an almost obsessive focus on the complicated and open-textured text itself."

The textualism employed by the First Circuit (and to a much lesser degree the Sixth Circuit) exhibits this obsession - to such a degree that this circuit's interpretive strategy is more accurately classified as either "literalism" or "strict textualism."

93527 US 471, 482 (1999) (noting that "[the dissent] relies on the legislative history of the ADA for the contrary proposition that individuals should be examined in their uncorrected state [for the purposes of determining whether they have a disability]," but that "[b]ecause we decide that, by its terms, the ADA cannot be read in this manner, we have no reason to consider the ADA's legislative history").

94 Id.

95 See id at 500-02 (Stevens dissenting) (pointing out that both the Senate Report and the Report of the House Committee on Education and Labor explicitly state that "whether a person has a disability should be assessed without regard to the availability of mitigating measures, such as reasonable accommodations or auxiliary aids") (citation omitted).

96 Cynthia Estlund, The Supreme Court's Labor and Employment Cases of the 2001-2002 Term, 18 Labor Law 291, 306-07 (2002). See also Colker, The Disability Pendulum at 208-12 (cited in note 7) (noting the "ahistorical" approach the Court takes to the ADA); Matthew Diller, Judicial Backlash, the ADA, and the Civil Rights Model, 21 Berkeley J Empl \& Labor L 19, 21 (2000) ("Despite judicial claims that the courts are simply applying the 'plain meaning' of the statute, the courts are choosing narrow readings over broad ones, even in the face of expansive administrative interpretation and strong evidence that Congress intended the statute to be interpreted broadly.").

97 See Cass R. Sunstein, Is Tobacco a Drug? Administrative Agencies as Common Law Courts, 47 Duke L J 1013, 1051-54 (1998) (defining this sort of interpretive framework as "literalism"). See also Daniel A. Farber, The Inevitability of Practical Reason: Statutes, Formalism, and the Rule of Law, 45 Vand L Rev 533, 547-54 (1992) (defending judicial formalism - that is, literalism - on the grounds that it promotes the rule of law).

98 See William N. Eskridge, Jr., All about Words: Early Understandings of the "Judicial Power" in Statutory Interpretation, 1776-1806, 101 Colum L Rev 990, 1088 (2001) (associating "strict textualism" with Scalia's views on originalism and legislative history). Consider also Melvin Aron Eisenberg, Strict Textualism, 29 Loyola LA L Rev 13, 37-38 (1995) ("Strict textualism reflects not 
looks solely to the "plain language" of Title II, refusing to consider either statutory context or purpose. For example, the court in Iverson reasons that the absence of particular dates for compliance in the ADA indicates that the transition plan regulation's specific temporal requirements render its obligations more extensive than Title II itself." A closer look at the implicit sources by which Sandoval establishes its "prohibits what the statute permits" test, however, argues for a less literal-minded interpretive framework.

\section{RESOLUTION OF THE CIRCUIT SPLIT}

The circuit split turns on the question of whether Sandoval's "prohibit what the statute permits" test should be analyzed under a textualist or intentionalist interpretive methodology. Courts on both sides of the split cite Sandoval to guide their analysis of statutory scope ${ }^{100}$ Lacking, however, is an interpretive middle ground - "contextualism"which may prove a more accurate framework with which to assess the relation between Title II and its implementing regulations.

Given this oversight, this Part concludes that an autotelic application of the Sandoval framework is by itself inadequate to solve the disagreement at the heart of the circuit split. Specifically, Part III.A introduces the potential middle-ground interpretive methodology of contextualism. Part III.B then argues that the lower courts' misplaced reliance on Sandoval's ostensible textualism overlooks an important interpretive alternative. Namely, this Part argues that Sandoval's implicit invocation of nondelegation principles cannot justify a textualist interpretive methodology. Part III.C then proposes an alternative (contextualist) framework adopted by the Court in Jackson, a Title IX retaliation case, concluding that through Jackson the Supreme Court enumerated and formalized much of Sandoval's analysis. Part III.C applies the Jackson framework to Title II and its implementing regulations, hypothesizing that under the three-part Jackson inquiry, Title II creates a private right of action to enforce self-evaluation and transition plans.

\section{A. Contextualism}

Before embarking on an analysis of contextualism as a satisfactory solution to the circuit split, the interpretive methodology must be defined. At the moment, there are at least three theories that assume the appellation "contextualism" in legal commentary. At one extreme,

the obedience that the court owes to the legislature, but an improper and indeed arrogant move by a subordinate to assume a role that is equal or even dominant to that of his master.").

$99452 \mathrm{~F} 3 \mathrm{~d}$ at 101.

100 See Part II. 
contextualism has been described as a pseudo-canon of construction whereby statutory words must be construed to accommodate their position in sentences, paragraphs, sections, or parts of a statute. ${ }^{101}$ At the other extreme, some commentators use contextualism to refer to a genus of interpretive strategies that includes intentionalism and purposivism. ${ }^{102}$ For other commentators, contextualism is best conceived as an interpretive methodology that takes account of the historical and legislative context in which a statute was enacted to divine its meaning. ${ }^{103}$ More generally, however, it is possible to understand all these contextualist strategies as points on a continuum-with their differences merely of degree. ${ }^{104}$ For the purposes of this Comment, contextualist interpretation will be understood simply as a textualist hybrid that looks to legal and historical context to understand broadly worded statutory language, but does not use legislative history or otherwise inquire into extra-textual manifestations of congressional intent.

For several reasons, a contextualist interpretive strategy is particularly well suited to analyze Title II's statutory scope under the "prohibits what the statute permits" test. Title II, like other civil rights statutes, is specifically modeled after Title VI of the Civil Rights Act of 1964. Moreover, the statute acquired much of its operative language from $\S 504$ of the Rehabilitation Act. As a result of these similarities, it appears that the drafters of Title II had certain expectations about how the statute's text was to be understood by the judiciary - and any interpretive attempt that fails to account for these expectations is in danger of misreading the "plain meaning" of the text. More generally, Title II, like its civil rights brethren, does not trade in specificity: its language is broad and potentially ambiguous. In fact, some courts, recognizing Title II's textual ambiguity, have even used the more specific

101 See, for example, Lon L. Fuller, Positivism and Fidelity to Law-A Reply to Professor Hart, 71 Harv L Rev 630, 667 (1958) ("[W] [hen [the words of a statute] are all part of a single structure of thought, they are in interaction with one another during the process of interpretation.").

102 See Robert J. Martineau, Craft and Technique, Not Canons and Grand Theories: A Neo Realist View of Statutory Construction, 62 Geo Wash L Rev 1, 15-19 (1993) ("Two categories of the contextualist approach are intentionalism (as demonstrated by the imaginative reconstruction approach of Judge Posner) and purposivism (as demonstrated by the legal process approach of Hart and Sacks).").

103 See, for example, Robert J. Araujo, The Use of Legislative History in Statutory Interpretation: $A$ Look at Regents v. Bakke, 16 Seton Hall Leg J 57, 91-92 (1992) (noting that judicial interpretation of a statute should be "concerned with the temporal and factual contexts surrounding" it). See also Jonathan R. Siegel, What Statutory Drafting Errors Teach Us about Statutory Interpretation, 69 Geo Wash L Rev 309, 348 (2001) (detailing the different interpretive techniques to which the "contextualist" label has been applied).

104 See Sunstein, 47 Duke $L \mathrm{~J}$ at 1051-52 (cited in note 97). 
language of the statute's implementing regulations to interpret Title II's broad language! ${ }^{105}$

\section{B. A Misplaced Reliance on Sandoval's Ostensible Textualism}

Both circuits denying a private right of action under Title II's selfevaluation and transition plan regulations have employed a textualist analysis based primarily on Sandoval's purportedly textualist bent. Nevertheless, given the nondelegation principle, which appears to underlie the Court's conclusion in Sandoval, this textual reliance may be misplaced. Namely, while commentators have recognized the importance of the nondelegation principle in textualist theories of interpretation and canons of construction, the historical judicial application of nondelegation appears to exhibit a more liberal theory of statutory interpretation. Moreover, the principles underlying nondelegation generally corroborate the use of a contextualist (rather than intentionalist) interpretive strategy, as is demonstrated in a recent Supreme Court case concerning retaliation claims under Title IX.

1. The nondelegation doctrine favors a contextualist application of Sandoval.

Although Sandoval does not explicate the constitutional basis for its holding, an analysis of its citations indicates a tacit reliance on the nondelegation doctrine. Namely, the Court in Sandoval notes that the implicit basis for its test is "a particular understanding of the genesis of private causes of action." 106 This understanding mandates that, "[l]ike substantive federal law itself, private rights of action to enforce federal law must be created by Congress." "For support, the Court cites a long line of cases emanating from an early twentieth century

105 See Parker v Universidad de Puerto Rico, 225 F3d 1, 5 (1st Cir 2000) ("The language of Title II does not elaborate on the obligation of a public entity to an individual with a disability in the provision of 'services, programs, or activities' We must rely for specifics on the regulations promulgated under Title II.") (citation omitted). Given these factors, it is surprising that the Supreme Court continues to prefer textualism in its interpretation of the ADA. See, for example, Sutton, 527 US at 482 . One commentator has suggested that the apparent resistance of a majority on the Court to a less literal interpretation of the ADA arises from the textualist preference for a colloquial definition of "disability." See Parmet, Plain Meaning and Mitigating Measures at 145-48 (cited in note 88 ). Others view the more limiting interpretive strategy as part of a larger conscious effort to limit the ADA's influence. See generally, for example, Diller, 21 Berkeley J Empl \& Labor L 19 (cited in note 96) (arguing that judicial skepticism of the ADA's "civil rights model" of disability contributes to decisions constraining the ADA's scope).

106532 US at 286.

107 Id (emphasis added), citing Touche Ross \& Co v Redington, 442 US 560, 578 (1979). The Court famously quips, "[a]gencies may play the sorcerer's apprentice, but not the sorcerer himself." Sandoval, 532 US at 291. 
conception of Article I, $\S 1$ of the Constitution. ${ }^{108}$ This conception provided that Congress, being endowed singularly with lawmaking power, could not constitutionally delegate this power to the executive-the nondelegation doctrine. ${ }^{109}$ At the roots of this case law appears a formalization of the doctrine, detailing that

[t] he power of an administrative officer or board to administer a federal statute and to prescribe rules and regulations to that end is not the power to make law-for no such power can be delegated by Congress - but the power to adopt regulations to carry into effect the will of Congress as expressed by the statute. ${ }^{110}$

Sandoval's implicit invocation of the nondelegation doctrine serves to buttress the Court's inquiry into Title VI-and perhaps insinuates that the "prohibit what the statute permits" test should be analyzed under a textualist framework. While the constitutional merits of the nondelegation doctrine are widely debated, ${ }^{111}$ the Court and some commentators have correctly recognized nondelegation's influence on theories of textualist statutory interpretation and doctrinal canons of construction. ${ }^{112}$ In Sandoval, the Court ostensibly appeals to the textualist implications of nondelegation, noting that precedent requires the "language" of the statute to control and finding that a regulation may only summon a cause of action Congress created "through statutory

108 See Sandoval, 532 US at 286. Sandoval supports its assertion with Touche Ross \& Co, 442 US at 577 n 18, which cites Ernst \& Ermst v Hochfelder, 425 US 185, 214 (1976). Ernst, in turn, cites Manhattan General Equipment Co v Commissioner of Internal Revenue, 297 US 129, 134 (1936), for the proposition that "[t]he rulemaking power granted to an administrative agency... is not the power to make law." Ernst, 425 US at 213-14.

109 For a general overview of the nondelegation doctrine's history, see Clinton $v$ City of New York, 524 US 417, 484-86 (1998) (Breyer dissenting); David Epstein and Sharyn O'Halloran, Delegating Powers: A Transaction Cost Politics Approach to Policy Making under Separate Powers 19-20 (Cambridge 1999).

110 Manhattan General Equipment, 297 US at 135 (emphasis added).

111 See, for example, Eric A. Posner and Adrian Vermeule, Interring the Nondelegation Doctrine, 69 U Chi L Rev 1721, 1722 (2002) ("The nondelegation [doctrine] lacks any foundation in constitutional text and structure, in standard originalist sources, or in sound economic and political theory.").

112 See Mistretta v United States, 488 US 361, 373 n 7 (1989) ("In recent years, our application of the nondelegation doctrine principally has been limited to the interpretation of statutory texts, and, more particularly, to giving narrow constructions to statutory delegations that might otherwise be thought to be unconstitutional.") (emphasis added); John F. Manning, The Nondelegation Doctrine as a Canon of Avoidance, 2000 Sup Ct Rev 223, 237-38 (discussing Mistretta); John F. Manning, Textualism as a Nondelegation Doctrine, 97 Colum L Rev 673, 675 (1997) (concluding that "textualism should be understood as a means of implementing a central and increasingly well-settled element of the separation of powers - the prohibition against legislative self-delegation"); Cass R. Sunstein, Nondelegation Canons, 67 U Chi L Rev 315, 315-16 (2000) (theorizing that the doctrine has been "relocated rather than abandoned" and is now vindicated through several canons of construction that constrain certain agency activities). 
text." ${ }^{113}$ This explicit reference to textual inquiry is common of textualist interpretive theory, which avers legitimacy from the bicameralism and presentment requirements for legislation."

Notwithstanding the Court's attempts in Sandoval to alleviate its implicit nondelegation concerns with a sort of "clear statement rule" derived through textualism, a historical analysis of the doctrine's application reveals a more ambivalent approach to statutory interpretation. Traditionally, the nondelegation doctrine required Congress, when delegating its legislative power to the executive branch, to "lay down by legislative act an intelligible principle to which the person or body authorized to [act] is directed to conform." 11 To determine whether a principle was "intelligible," a court was permitted to look to statutory context to find that an otherwise vague grant of power was not "so indefinite as to confer an unlimited power." tions of this review, a court was also permitted to investigate Congress's purpose to give specific meaning to a vague delegation of lawmaking authority. ${ }^{17}$ This historical inquiry, which is emblematic of a contextualist theory of statutory interpretation, reveals a tradition of judicial deference to Congress's delegation of its legislative power.

Deference in the context of the traditional nondelegation doctrine and in the case of Sandoval's implication of a private right of action may differ substantially enough, however, to require a textualist inquiry into the scope of statutory permissibility. Specifically, if the Sandoval test can be construed as a "nondelegation canon," perhaps requiring a more literal interpretation of what the organic statute permits will be necessary. ${ }^{119}$ Under a nondelegation canon theory, "the nondelegation canons [generally] have the salutary function of insuring that important rights and interests will not be compromised unless

113532 US at 291 (emphasis added).

114 Scalia himself, as well as other prominent textualists, occasionally defends textualism on the grounds that it follows from Article I's requirements of bicameralism and presentment. See, for example, Scalia, $A$ Matter of Interpretation at 3, 9-13, 34-35 (cited in note 89). For the connections between bicameralism, presentment, and nondelegation, see John F. Manning, The Absurdity Doctrine, 116 Harv L Rev 2387, 2434 n 179 (2003) ("Similarly, the nondelegation doctrine, to the extent that it still has force, depends on structural inferences from the constitutional prescription of bicameralism and presentment.").

115 J.W. Hampton, Jr., \& Co v United States, 276 US 394, 409 (1928) (emphasis added).

116 See Federal Radio Commission v Nelson Brothers Bond \& Mortgage Co, 289 US 266, 285 (1933) (finding that a standard of "public convenience, interest, or necessity" was to be interpreted "by its context").

117 See Clinton, 524 US at 489 (Breyer dissenting) ("[C]ontext and purpose can give meaning to highly general language.").

118 See Sunstein, $67 \mathrm{U}$ Chi L Rev at 316 (cited in note 112).

119 See generally id. Under this conception, the Sandoval test would be equivalent to a canon that reads, "An organic statute can confer its private right of action on an implementing regulation only if the regulation prohibits behavior explicitly in the statute's scope." 
Congress has expressly decided to compromise them." ${ }^{120}$ Since these canons of construction do not create institutional problems of judicial competence, ${ }^{121}$ perhaps this less deferential mode of statutory interpretation is preferable.

Nonetheless, while the function of the Sandoval test as a nondelegation canon perhaps rules out a traditional intentionalist inquiry, the underlying policy goals of the nondelegation doctrine appear to be best satisfied under a contextualist, rather than textualist, interpretive strategy. One important justification for the nondelegation doctrine is that by requiring legislatures to draft specific language when delegating legislative power, the burdens and costs to Congress of creating linguistic specificity will require any delegation to be the product of democratic consensus. ${ }^{123}$ There is no reason to believe, however, that a more literal interpretation of the organic statute will differentiate statutes based on democratic consensus from those that are the product of special interest lobbying. Namely, Congress's views on what constitutes specific language are largely contextual-influenced to a significant degree by how the judiciary has interpreted prior legislation. In the case of Title II, for example, congressional drafters appear to have specially modeled the statute's language after that of the Civil Rights Act of 1964 and $\S 504$ of the Rehabilitation Act, with the expectation that courts would rule on its provisions similarly. ${ }^{124}$ Given this reasonable expectation, perhaps the language agreed upon was in fact considered "specific" by the enacting Congress.

Especially in the case of inferring private rights of action, an overly deferential attitude toward Congress may be counterproductive. One problem nondelegation appears to address is the infringement of certain rights without the protections of democratic deliberation. ${ }^{125}$ Private rights of action, however, grant individual rights. Con-

120 Id at 338 (emphasis added).

121 See id at $326-28,338$.

122 One potential argument for literalism in these situations is that it would encourage greater clarity from Congress. See Sunstein, 47 Duke L J at 1053 (cited in note 97) ("[L]iteralism can be justified as analogous to an information-eliciting rule in the law of contract, designed to force the parties (or in this case, the Congress) to speak with greater clarity.").

123 See Sunstein, 67 U Chi L Rev at 320 (cited in note 112). See also Epstein and O'Halloran, Delegating Powers at 51 (cited in note 109):

When legislators make all important policy decisions themselves, which is equivalent to congressional policy making, agencies have no discretion. When laws leave the details of public policy to the executive to fill in, then agencies have greater discretion. And it is Congress who chooses a point along this continuum by writing detailed or broad legislation.

124 See note 14.

125 See Sunstein, $67 \mathrm{U}$ Chi L Rev at 320-21 (cited in note 112) ("[T]he requirement of legislative clarity might also seem to be a check on the problems of factional power and selfinterested representation, two of the problems most feared by the framers. Indeed, the nondele- 
sequently, the concern for deliberative democracy may not be as acute in these situations. In fact, when agencies grant individual rights without foreclosing other individual rights, perhaps the judiciary should generally be more deferent to the agency rule. The right to sue, of course, will inevitably remove a corollary right of some entity not to be sued-and this may well be a right worth protecting through nondelegation. Where however, as in the case of Title II, the entity giving up the right not to be sued is public, sovereign immunity seems a more direct method of protecting these public entities than a roundabout clear statement principle functioning as nondelegation's modern avatar.

Just as principles of judicial minimalism cast doubt on the use of literal textualism in the nondelegation context, concerns about subversion of the legislative process argue for a more suspicious attitude toward legislative history. As previously mentioned, the generally accepted virtue of a statutory interpretation species of nondelegation is that clear statement rules decrease the opportunity for special interest groups to capture the legislative process and raise the decision costs of legislation. ${ }^{126}$ While a contextualist interpretive methodology accounts for the unspoken and perhaps unconscious congressional preferences expressed through linguistic context, intentionalism goes one step further, evaluating spoken and presumably conscious preferences, which, as commentators and judges have recognized, can be manipulated by special interest groups. ${ }^{127}$ In this regard, contextualism, offering a middle-ground approach, best addresses the concerns underlying nondelegation in statutory interpretation.

\section{Jackson formalizes the contextualist reading of Sandoval.}

A recent Supreme Court case, Jackson, formalizes this contextualist framework for analyzing statutory scope under Sandoval. In Jackson, a women's basketball coach brought suit under Title IX, claiming his dismissal was retaliation for his vocal complaints about the lack of support for women's sports at the school. ${ }^{128}$ The Court ruled that although such retaliation was explicitly prohibited only by a Department of Education implementing regulation, a contextualist reading of Title IX's broad language preempted the standard Sandoval analysis. ${ }^{129}$ Specifi-

gation doctrine might be taken as a central means of reducing the risk that legislation will be a product of efforts by well-organized private groups to redistribute wealth or opportunities in their favor.").

126 See Manning, 2000 Sup Ct Rev at 238-42 (cited in note 112). See also notes 114, 121, and 122.

127 See, for example, Scalia, A Matter of Interpretation at 34 (cited in note 89) ("One of the routine tasks of the Washington lawyer-lobbyist is to draft language that sympathetic legislators can recite in a prewritten 'floor debate' - or, even better, insert into a committee report.").

128 See 544 US at 171-72.

129 See id at $177-78$. 
cally, finding that "the statute itself contains the necessary prohibition" against intentional discrimination, Justice O'Connor, writing for the majority, concluded that the plaintiff was not obliged to derive a private right of action from the implementing regulation. ${ }^{130}$ While the Court explicitly refused to analyze this claim under Sandoval's test, it noted in dicta that such an analysis would not have materially affected its decision $^{131}$-indicating that Jackson's interpretive methodology is equally applicable to similar cases brought under Sandoval. Because this methodology depends on the legal setting in which Title IX was drafted, it appears that statutory context could be relevant under Sandoval.

The Jackson Court's interpretive inquiry, unlike Sandoval's, presents a concrete methodology for determining whether a statute's regulatory scope includes the behavior challenged in a private actionusing interpretive strategies best classified as contextualist. In Jackson, the Court initially focused on the language of Title IX, determining that its "broad[] prohibit[ion]" against discrimination on the basis of sex, coupled with prior Court precedent construing Title IX expansively, required a broad reading of the text to include retaliation. ${ }^{132}$ To determine the scope of this broad language, the Court surveyed judicial precedent decided before Title IX's enactment, concluding that prior legal interpretation "provides a valuable context for understanding the statute" since it elucidates congressional choice of language. ${ }^{133}$

130 Id at 178 ("[T] person who speaks out against sex discrimination, because such retaliation is intentional 'discrimination' on the basis of sex.").

131 See id ("In step with Sandoval, we hold that Title IX's private right of action encompasses suits for retaliation, because retaliation falls within the statute's prohibition of intentional discrimination on the basis of sex."). See also id at $178 \mathrm{n} 2$ ("We agree with [the dissent] that plaintiffs may not assert claims ... for conduct not prohibited by that statute... But we part ways with regard to our reading of the statute.").

132 Id at 173, 175 (rejecting a literalist approach, since, because "Title IX is a broadly written general prohibition on discrimination, followed by specific, narrow exceptions to that broad prohibition," congressional "failure to mention one such practice does not tell us anything about whether it intended that practice to be covered").

133 Id at 176. The Court notes that Sullivan v Little Hunting Park, Inc, 396 US 229 (1969), was decided merely three years before Title IX was enacted. Jackson, 544 US at 176. Sullivan held that 42 USC $\$ 1982$, which provides that "[a]ll citizens of the United States shall have the same right ... as is enjoyed by white citizens ... to inherit, purchase, lease sell, hold, and convey real and personal property," protected retaliation claims by those who enabled black citizens to leasehold property. See 396 US at $236-40$ (citations omitted). 
C. Under Jackson's Contextualist Analysis, Title II Provides a Private Right of Action to Enforce Compliance with Transition and Self-Evaluation Plans

In Jackson, the Court found several aspects of Title IX probative to the statute's extension to retaliation claims: the Court noted that Title IX "is a broadly written general prohibition on discrimination, followed by specific, narrow exceptions to that broad prohibition"; ${ }^{32}$ that judicial precedent had "repeated[ly] ... constru[ed] 'discrimination' under Title IX broadly"; $;$ " and that the historical-legal context in which Title IX was introduced "provides a valuable context for understanding the statute." ${ }^{136}$ An analysis of Title II's historical-legal context finds many similarities with Title IX-suggesting that under Jackson's contextualist analysis, self-evaluation and transition plan regulations should be enforceable through a private right of action.

1. Title II is a broadly written statute reminiscent of Title IX.

Title II and Title IX, both being derived structurally from Title VI of the Civil Rights Act, contain remarkably similar language. Title IX provides that "[n]o person in the United States shall, on the basis of sex, be excluded from participation in, be denied the benefits of, or be subjected to discrimination under any education program or activity receiving Federal financial assistance." ${ }^{137}$ In virtually identical language, Title II provides, "[N]o qualified individual with a disability shall, by reason of such disability, be excluded from participation in or be denied the benefits of the services, programs, or activities of a public entity, or be subjected to discrimination by any such entity.", Moreover, like Justice O'Connor documented in Jackson about Title IX, Title II is "followed by specific, narrow exceptions to [its] broad prohibition," ${ }^{139}$ suggesting that the failure of Title II to mention transition or self-evaluation plans is not necessarily material.

A more complicated question, however, is whether failure to create a transition plan or self-evaluation plan, like retaliation in Jackson, can plausibly be construed as "exclud[ing] [an individual with a disability] from participation in or den[ying] the benefits of services, programs, or activities of a public entity." ${ }^{140}$ While a standard plain lan-

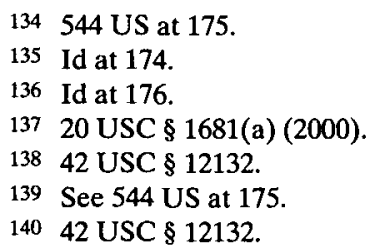


guage reading of Title II would probably deny that transition or selfevaluation plans are "services, programs, or activities," the Jackson majority would disagree. In Jackson, because retaliation was both "intentional" and "discriminatory" under the broadest reading of those terms, the Court found a private right of action to enforce retaliation claims. ${ }^{142}$ Since a refusal to create a self-evaluation plan or a transition plan is simply a "denial," and because either plan can arguably be classified as a "service," ${ }^{143}$ it appears that, under the accommodating Jackson analysis, transition and self-evaluation requirements can plausibly fit within Title II's regulatory scope.

2. Courts have interpreted "programs, services, and activities" in Title II liberally.

Title II's broad language, and particularly its directive that no otherwise qualified individual shall "be denied the benefits of the services, programs, or activities of a public entity," ${ }^{14}$ has, like Title IX, been construed to apply to a wide range of factual situations. As previously mentioned, courts have interpreted Title II to govern: the availability of physical access to public facilities, ${ }^{145}$ including courtrooms, ${ }^{146}$ polling places, ${ }^{147}$ prisons, ${ }^{148}$ and public restrooms; ${ }^{149}$ and the availability of services such as equal educational opportunities ${ }^{150}$ and accessible transportation. ${ }^{151}$ One case in particular, Klinger $v$ Director, ${ }^{152}$ is emblematic of the liberal judicial interpretation of "services." In Klinger, the Eighth Circuit held that a municipality violated Title II by requiring disabled individuals buying placards indicative of handicapped status to pay a surcharge. ${ }^{1.53}$ Although the court noted that "services" did not encompass the specific form of handicapped plac-

141 See, for example, Ability Center, 385 F3d at 914.

142 See 544 US at 173-74 ("Retaliation is, by definition, an intentional act. It is a form of 'discrimination' because the complainant is being subjected to different treatment.").

143 While the self-evaluation and transition plans provide no immediate physical benefit, each facilitates the transformation of structural and programmatic facilities as contemplated by the ADA. A "service" is commonly defined as "an act done for the benefit ... of another," and can include "deeds useful or instrumental toward some object." Webster's Third New International Dictionary of the English Language 2075 (Merriam-Webster 1993) (emphasis added).

14442 USC \& 12132 (emphasis added).

145 See note 21.

146 See note 22.

147 See note 23.

148 See note 24.

149 See note 25.

150 See note 26.

151 See note 27.

152433 F3d 1078 (8th Cir 2006).

153 See id at 1082. 
ards, Title II and its implementing regulations did "anticipate the use of reserved parking spaces" for individuals with disabilities. ${ }^{\text {1st }}$

This broad reading of Title II has not been confined to the lower courts. In Pennsylvania Department of Corrections v Yeskey, ${ }^{155}$ the Supreme Court rejected an argument that prison programs and services were not regulated by the ADA. ${ }^{156}$ The Court, finding no reason to distinguish prison services from others under Title II, noted that "[m]odern prisons provide inmates with many recreational 'activities,' medical 'services,' and educational and vocational 'programs,' all of which at least theoretically 'benefit' the prisoners (and any of which disabled prisoners could be 'excluded from participation in')." ${ }^{157}$ In lieu of this broad precedent, cataloging transition and self-evaluation plans under "services, programs, and activities" is not an illogical interpretive leap.

3. Title II's language and scope was informed by the Rehabilitation Act.

The ADA's explicit reliance on the Rehabilitation Act of 1973, like Title IX's implicit reliance on historical case law, indicates that Congress intended to create a private right of action to enforce Title II's transition and self-evaluation plan regulations. Textual and legislative evidence details the ADA's explicit reliance on the Rehabilitation Act. The two statutes share an identical definition of disability, ${ }^{158}$ and Title II and $\S 504$ of the Rehabilitation Act contain a remarkably similar prohibition against the denial of services and benefits. ${ }^{159}$ Moreover, both Congress and lower courts have recognized the ADA's dependence on the language of, and prior precedent interpreting, the Rehabilitation Act. The House Report accompanying the ADA states that Title II $\S 202$ "extends the nondiscrimination policy in $\S 504$ of the Rehabilitation Act of 1973 to cover all State and local governmental entities." ${ }^{160}$ Congress has advocated consistent interpretation of similar ADA and Rehabilitation Act provisions in order to "prevent imposition of inconsistent or conflicting standards for the same require-

154 Id at 1080 (emphasis added).

155524 US 206 (1998).

156 See id at 210 .

157 Id.

158 Compare 42 USC $\$ 12102$ (2)(a) (ADA), with 29 USC $\$ 705(9)$ (B) (Rehabilitation Act).

159 Compare 42 USC $\$ 12132$ (ADA) ("[N]o qualified individual with a disability shall, by reason of such disability, be excluded from participation in or be denied the benefits of the services, programs, or activities of a public entity."), with 29 USC \& 794(a) (Rehabilitation Act) ("No otherwise qualified individual ... shall, solely by reason of her or his disability, be excluded from the participation in, be denied the benefits of, or be subjected to discrimination under any program or activity ... conducted by any Executive Agency.").

160 HR Rep No 101-485(II), 101st Cong, 2d Sess 84 (1990), reprinted in 1990 USCCAN 367. 
ments" under different statutory schemes. ${ }^{161}$ Lower courts, when interpreting the ADA, have integrated prior decisions interpreting the Rehabilitation Act. ${ }^{16}$

Since Title II, moreover, explicitly adopts the enforcement scheme of the Rehabilitation Act, a contextualist reading of the statute would conclude that Title II's drafters intended it to extend the Rehabilitation Act's remedial regime - which includes regulations implementing transition and self-evaluation plans. Namely, Title II mandates that the Attorney General should promulgate regulations consistent with the Rehabilitation Act's existing implementing regulations. ${ }^{163}$ These regulations include requirements of a transition plan ${ }^{164}$ and self-evaluation plan. ${ }^{165}$ Thus, requiring a transition or self-evaluation plan could have been comprehended by Congress when it drafted Title II. More importantly, however, in 1985, the Supreme Court in Alexander $v$ Choate $^{166}$ found that the Rehabilitation Act, unlike Title VI of the Civil Rights Act, prohibits disparate impact discrimination. ${ }^{167}$ As a result, at the time the ADA was drafted, congressional drafters had no reason to believe that Title II's private right of action would not extend to instances of disparate impact discrimination - and no reason to believe that violation of transition plan and self-evaluation plan regulations was not an instance of disparate impact discrimination.

\section{CONCLUSION}

This Comment proposes a new interpretive methodology for Sandoval's "prohibit what the statute permits" test. It argues that both the historical application of and policy goals underlying the nondelegation doctrine, in addition to a recent Supreme Court case construing Title IX's scope, buttress a conclusion that what the organic statute "permits" should be analyzed under a contextualist interpretive framework. This solution will not only provide a much-needed remedy under Title II's transition plan and self-evaluation plan regulations, but also provide the proper motivation for public entities to facilitate compliance with ADA Title II.

161 See 42 USC $\$ 12117(b)$.

162 See, for example, Andrews v Ohio, 104 F3d 803, 807 (6th Cir 1997) ("Because the standards under both of the acts are largely the same, cases construing one statute are instructive in construing the other."); Wooten v Farmland Foods, 58 F3d 382, 385 n 2 (8th Cir 1995) ("The ADA defines disability substantially the same as the Rehabilitation Act of 1973 defines handicap, ... so cases interpreting either will be instructive for [a court's] analysis.").

163 See 42 USC $\$ 12134$ (a)-(b).

164 See 28 CFR $\$ 39.150$ (d).

165 See 28 CFR $\$ 39.110$.

166469 US 287 (1985).

167 See id at 295-99. 